\section{The \\ University \\ of Chicago \\ Law Review}

VOLUME 40 NUMBER 2 WINTER 1978

\title{
Ernst Freund and the First Amendment Tradition
}

\author{
Professor Ernst Freund and Debs v. United States \\ Harry Kalven, Jr.†
}

The decision in Debs $v$. United States ${ }^{1}$ was handed down by the United States Supreme Court some fifty-four years ago. It is happily no longer good law; it is not likely to become law again. It is with little exception not studied in the law schools, and it is rarely cited or noted in even the more elaborate casebooks or treatises on constitutional law. ${ }^{2}$ It might seem, therefore, an antiquarian indulgence for a busy law review to devote some pages to it, especially for the primary purpose of reprinting an article from the New Republic, an article which is also fifty-four years old. ${ }^{3}$

But the opinion in Debs was written by Justice Holmes; and the article in the New Republic is a criticism of the case written by Ernst Freund. Taken together these facts provide important clues to the intellectual history of the first amendment tradition, a history we had better understand if we are to hang on to the tradition today. We would do well to be aware of how far we have traveled and how difficult it was

$\dagger$ Professor of Law, The University of Chicago.

1249 U.S. 211 (1919).

2 The major exception appears to be G. Gunther \& N. Dowling, Gases and Materials on Constrututional LAW 1061 (8th ed. 1970) (using Debs as a principal case). See also C. Pritchetr, The American Constitution 416 (2d ed. 1968) (devoting a few lines' brief to it). Z. Chafee, Free Spefch in the United States $84-85$ (rev. ed. 1948) does discuss it. See text at note 12 infra.

3 Except for the reference to it in Z. ChafeE, supra note 2, it might well have been beyond reach for scholarly as well as popular audiences. 
to get here. We need, in Learned Hand's splendid phrase, to have a sense of our "hard bought acquisition in the fight for freedom."

The constitutional law dimension of American free speech and political tolerance dates, as we all know, from the opinion of Justice Holmes in Schenck $v$. United States, ${ }^{5}$ one of the most cited and famous of American cases. It is that opinion which gave to the law, and to the culture, the "clear and present danger" formula for measuring the reach of the first amendment, and which gave us also the example of the man falsely shouting fire in the crowded theater. For better or for worse, and I believe it for worse, the formula and the example have loomed very large in the subsequent development of first amendment interpretation. ${ }^{6}$

It has been customary to lavish care and attention on the Schenck case. The point we need for present purposes is simply that Debs $v$. United States had been argued to the Court well before Schenck was decided and was itself decided March 10, 1919, just one week later than Schenck. It represented the first effort by Justice Holmes to apply what he had worked out about freedom of speech in Schenck. The start of the law of the first amendment is not Schenck; it is Schenck and Debs read together.

Read freshly with the eyes of today the outcome in Debs is shocking. Debs was charged with obstructing recruitment for the draft in violation of the Espionage Act of 1917. He was convicted and given a ten-year prison sentence. ${ }^{7}$ His criminal conduct consisted of a public speech to a general audience in Canton, Ohio. "The main theme of the speech," Justice Holmes tells us, "was socialism, its growth, and a prophecy of its ultimate success." In the course of the speech, Debs expressed sharp criticism of war in general, and of World War I in particular, from the socialist point of view: "the master class has always declared the wars and the subject class has always fought the battles." He also expressed sympathy for several others already convicted and imprisoned for their opposition to the war, saying as to Rose Pastor Stokes "if she was guilty so was he." Justice Holmes, in a curious show of empathy, quotes several other passages from the speech and from Debs's statement to the jury: "Don't worry about the charge of treason to your masters; but be concerned about the treason that in-

4 Masses Publishing Co. v. Patten, 244 F. 535, 540 (1917).

5 249 U.S. 47 (1919).

- The law may finally have worked itself pure. See Brandenburg v. Ohio, 395 U.S. 444 (1969).

T The prison sentence was commuted by President Harding in 1921, but Debs's citizenship was not restored. 
volves yourselves." "I have been accused of obstructing the war. I admit it. Gentlemen, I abhor war. I would oppose the war if I stood alone."8

The speech then fell into the genre of bitter criticism of government and government policy, sometimes called seditious libel; freedom of such criticism from government censorship marks, we have come to understand, "the central meaning of the First Amendment." During the Vietnam War thousands of utterances strictly comparable in bitterness and sharpness of criticism, if not in literacy, were made; it was pretty much taken for granted they were beyond the reach of government.

There is just one more detail for our brief. Debs at the time of the speech was a national political figure. He was to run for President the following year on the Socialist ticket and, although in prison at the time, was to receive almost 900,000 votes, a considerable fraction of all votes cast in the 1920 election. To put the case in modern context, it is somewhat as though George McGovern had been sent to prison for his criticism of the war.

The Debs case thus put a vital, practically important test of political dissent to the Court and the Constitution. The Court's almost laconic affirmance of the conviction raises serious question as to what the first amendment, and more especially, what the clear and present danger formula can possibly have meant at the time. Justice Holmes devotes only a single clause to the defendant's constitutional objections, noting merely that they were "disposed of in Schenck v. United States." He does not comment on the fact difference between the cases: the defendant in Schenck had sent his leaflets directly to men who awaited draft call whereas the defendant in Debs was addressing a general audience at a public meeting. Holmes offers no discussion of the sense in which Debs's speech presented a clear and present danger. ${ }^{10} \mathrm{He}$ shows no

8249 U.S. at 214.

9 New York Times v. Sullivan, 376 U.S. 254, 273 (1964); see Healy v. James, 408 U.S. 169 (1972); Street v. New York, 394 U.S. 576 (1969); Pickering v. Board of Educ., 391 U.S. 563 (1968); Bond v. Floyd, 385 U.S. 116 (1966).

10 While Justice Holmes does not pause to evaluate the danger from Debs's speech, he does, as Professor Freund notes, comment specifically on Debs's intention. After quoting Debs's statements to the jury about his hatred and abhorrence of war, Holmes observes:

The statement was not necessary to warrant the jury in finding that one purpose of the speech, whether incidental or not does not matter, was to oppose not only war in general but this war, and that the opposition was so expressed that its natural and intended effect would be to obstruct recruiting. If that was intended and if, in all the circumstances, that would be its probable effect, it would not be protected by reason of its being part of a general program and expressions of a general and conscientious belief.

Holmes's immediate concern at this point in the opinion is construing the federal statute and establishing that there was sufficient evidence of intention to permit a finding that 
sensitivity to accommodating a tradition of political dissent, a sensitivity which had so characterized Hand's opinion two years earlier in Masses Publishing Co. v. Patten, ${ }^{11}$ and makes no effort to suggest the parameters of improper criticism of the war. In fact the case did not move Justice Holmes to discuss free speech at all; his brief opinion is occupied with two points about admissibility of certain evidence at the trial. It was for Holmes a routine criminal appeal.

It was for Professor Freund, however, a dismal, and alarming, answer to the question of "freedom of agitation in wartime." His contemporary reaction to the decision serves to put into sharper focus the puzzles about Justice Holmes and the origins of the first amendment tradition. The Freund article makes it clear that the outcome in Debs was perceived as dangerously unsound by sophisticated legal intelligence of the day. If read with hindsight, Debs, as we said, now makes little sense and impeaches claims to serious freedom of speech; the Freund article shows that, read at the time, Debs made equally little sense.

Professor Chafee, after acknowledging that the Debs case came as a shock to many Holmes admirers, offered an explanation. "Looking backward, however, we see that Justice Holmes was biding his time until the Court should have before it a conviction so clearly wrong as to let him speak his deepest thoughts about the First Amendment." In the meantime Holmes, Chafee argues, by joining the majority in Schenck had been able to announce, with the backing of a unanimous Supreme Court, the rule of "clear and present danger." One more sentence, and Chafee's "benign plot" is completed. "The opportunity for which Justice Holmes had been waiting came eight months after Debs went to prison in Abrams v. United States."12

Professor Chafee is in one sense certainly correct. In Abrams, ${ }^{13}$ Holmes in dissent was moved to a burst of eloquence about free speech that was to enrich and permanently to alter the constitutional tradition of the first amendment. Afterwards, Debs is conveniently forgotten and the dissenting Abrams eloquence is read back into Schenck as though it had been there all the time. But however we interpret the sequence of precedents, we confront a blunt question, which the New Republic piece so dramatically underscores: What can it mean about Justice Holmes that it was Abrams and not Debs that finally stirred him to speak seriously about freedom of speech?

Debs had violated the statute. He offers no clue as to how intention and clear and present danger are related as tests of the first amendment.

11244 F. 535 (1917).

$12 \mathrm{Z}$. ChAFEE, supra note 2 , at 86 .

13250 U.S. 616 (1919). 
Ernst Freund has been a legendary figure for The University of Chicago Law School and its alumni. As one of the original faculty, he was a major architect of the school and a major source of its national visibility. He is remembered for his pioneer work in administrative law, comparative law, and legislation, and for his generous view of the scope of legal education. ${ }^{14}$ As the New Republic article shows, he is to be remembered, too, as a legal scholar playing a gallant role as public citizen. How welcome it is to know that amidst the patriotic pressures of World War I he could have written this sentence:

But stamp a man like Debs or a woman like Kate O'Hare as felons and you dignify the term felony instead of degrading them, and every thief and robber will be justified in feeling that some of the stigma has been taken from his crime and punishment.

\section{The Debs Case and Freedom of Speech*}

\section{Ernst Freund}

After the affirmance of his conviction by the Supreme Court, Mr. Debs issued a statement to the effect that the real issue, the constitutionality of the Espionage law, had not been decided, and such seems to be the general impression. As a matter of fact the decision raises inevitably the question of the freedom of agitation in war time. The offense of which Debs was convicted was obstruction of recruiting; the acts proved were a violent attack upon the war, its motives and objects, and the approval of the conduct and attitude of persons who had been convicted of like offenses; and from this evidence the jury was permitted to find a tendency and an intent to obstruct recruiting. There was nothing to show actual obstruction or an attempt to interfere with any of the processes of recruiting. How can it be denied that the upholding of such a finding upon such evidence involves the question of the limits of permissible speech? If verbal or written opposition to the war, however violent or unwarranted, can be stretched to mean a form of obstruction, then Congress strikes at utterances as effectually through punishing obstruction as though it punished utterances directly. Not only is to this extent the restraint of speech clearly sanctioned by the Supreme Court, but it is made to rest on judicial interpretation rather than upon legislation.

I shall not attempt to determine what in the way of restraint is

14 See Allen, Preface to E. Freund, Standards of American Legislation (1965 ed.).

- Reprinted from The NEW RePUblic, MAY 3, 1919, at 13. 
possible under the First Amendment. A narrow historic view (rather discountenanced by Justice Holmes) may confine freedom to the prohibition of censorship. Even so, with the post office under the control of the government, and in the absence of a clear and explicit constitutional right to the free and equal use of the postal service, Congress has it in its power to render the free expression of opinion harmless for immediate political purposes by denying mail facilities. It is therefore useless to over-emphasize the substantive limitations of the constitution; the real securities of rights will always have to be found in the painstaking care given to the working out of legal principles.

So long as we apply the notoriously loose common law doctrines of conspiracy and incitement to offenses of a political character, we are adrift on a sea of doubt and conjecture. To know what you may do and what you may not do, and how far you may go in criticism, is the first condition of political liberty; to be permitted to agitate at your own peril, subject to a jury's guessing at motive, tendency and possible effect, makes the right of free speech a precarious gift. Our practice has been so tolerant of political liberty and license that we have had no occasion to consider these things; Justice Holmes takes the very essentials of the entire problem for granted, and intimates that they are conceded even by the defendant.

On the continent of Europe, a harder and more recent struggle for the freedom of the press and for constitutional government in general induced a very much more scientific scrutiny of these fundamentals of penal responsibility, and instead of the illusory simplicity of our doctrines we find elaborately specified criteria of guilt. Over a hundred years ago Royer-Collard, the foremost exponent of the old-time French liberalism, in discussing a proposed law on the press, declared that in the matter of political offenses the recognition of such a thing as indirect provocation, i.e., implied or inferential incitement, spelled arbitrary power. This view finally gained acceptance, and the present French press law recognizes only direct provocation which has reference to some definite and particular criminal act, and punishes even direct provocation not resulting in actual crime only in connection with specified aggravated offenses. It is true that certain kinds of provocation are specially dealt with, and among these the incitement to military insubordination; and the German Penal Code has a general offense of direct incitement to disobedience to the laws; but the vagueness of definition that characterizes the Espionage Act, finds, I believe, no parallel in modern foreign legislation.

The Debs case itself illustrates most clearly the arbitrariness of the whole idea of implied provocation. A violent, if you please, a seditious, 
speech is made; a docile jury finds a design to obstruct recruiting, and the finding is conclusive because the court does not consider it inconsistent with possibility. What are the intrinsic probabilities? An experienced speaker like Debs knows the effect of words. He must have known that, while he might keep alive and even create disaffection, his power to create actual obstruction to a compulsory draft was practically nil, and he could hardly have intended what he could not hope to achieve; in fact it is difficult to conceive of a form of obstruction that can be opposed to a compulsory draft. I know of only one reported case of direct counselling not to report for military service when ordered so to do, and Judge Amidon in directing a verdict of acquittal in a recent case remarked upon the scarcity of overt acts, stating that all judicial decisions had dealt with the use of language. The inherent obstacles in the way of planning or carrying out obstruction certainly add to the intrinsic improbability of the imputed design. Yet Justice Holmes would make us believe that the relation of the speech to obstruction is like that of the shout of Firel in a crowded theatre to the resulting panic! Surely implied provocation in connection with political offenses is an unsafe doctrine if it has to be made plausible by a parallel so manifestly inappropriate.

It is well known that the Constitution in guaranteeing free speech makes no difference between peace and war time; if it did it would still be enormously difficult to formulate war time restraints as rules of law. On the continent of Europe the matter is handled by unregulated and arbitrary executive power, and the Prussian constitution expressly permits the suspension of the normal guarantees of freedom of speech and press in the emergency of war. The Espionage act is a crude piece of legislation, and, if it is the best that can be done, illustrates the inherent difficulties of the subject. For arbitrary executive, it practically substitutes arbitrary judicial, power; since a jury's findings, within the limits of a conceivable psychological nexus between words and deeds, are beyond scrutiny and control; and while the jury may have been a protection against governmental power when the government was a thing apart from the people, its checking function fails where government policies are supported by majority opinion. We fluctuate between constitutional immunity and common law uncertainty; the common law of political crimes was loose and arbitrary in the extreme, and, having fallen into gradual desuetude, has undergone no change or improvement in a hundred years. It was owing to this feature of it that the idea of a federal common law was altogether repudiated; but the criminal legislation of Congress, to which no adequate thought has ever been given, revives and perpetuates the defects of the common law. 
It even aggravates them, for sedition at common law is merely a misdemeanor, while congressional legislation, by failing to differentiate offenses according to the kind of culpability and grading only according to the maximum duration of punishment, causes every offense that is punishable by a sentence of imprisonment exceeding one year to assume the character of a felony. I do not speak of the draconic sentences imposed; they are clearly only "in terrorem," and since every one knows that they will not be carried out in full, they fail to terrorize and merely serve to create animosity and bitterness with reference to our processes of justice. But stamp a man like Debs or a woman like Kate O'Hare as felons, and you dignify the term felony instead of degrading them, and every thief and robber will be justified in feeling that some of the stigma has been taken from his crime and punishment.

Now that the war is virtually over, the Espionage act ceases to be effective, but since in time of war the voice of reason is not heard, or if heard is misconstrued, this is the time to protest against its legal unsoundness, and in the long run sound law cannot be inimical to sound policy. A country can ill spare the men who when the waves of militant nationalism run high do not lose the courage of their convictions. If that was true in Germany, it cannot be untrue of America. The peril resulting to the national cause from toleration of adverse opinion is largely imaginary; in any event it is slight as compared with the permanent danger of intolerance to free institutions. Fortunately public opinion in this country would not stand for the kind of legal terrorism that was practiced, for instance, in Italy. A certain amount of social terrorism must be accepted as inevitable; and if public opinion demands the prosecution of scurrilous and indecent attacks upon the cause for which a nation is fighting, local powers are adequate for that purpose.

No doubt a considerable public opinion also demands a federal prosecution of such attacks as were made by Debs and La Follette; but a wise government would have resisted that pressure. That sentiment has been gratified by creating an enormous amount of dissatisfaction, a dissatisfaction born of the conviction that what was prosecuted and punished was not action, but opinion. As in the case of all political persecution, the cause of the government has gained nothing, while the forces of discontent have been strengthened, and have been given an example of loose and arbitrary law which at some time may react against those who have set it. Toleration of adverse opinion is not a matter of generosity, but of political prudence. 
Professor Kalven points out that between Debs and Abrams there was a marked shift in Justice Holmes's thinking about the first amendment, a shift so fundamental that the Abrams dissent is viewed as the fountainhead of the first amendment tradition. It is, of course, impossible to gauge the extent to which Professor Freund's article contributed to that change. Yet there is evidence that Justice Holmes was acquainted with the article. His reactions to it, and to the opinions of another prominent critic of the Debs decision, Judge Learned Hand, mark the starting point in the movement from Debs to the Abrams dissent.

In Masses Publishing Co. v. Patten, ${ }^{1}$ Judge Hand had construed the sections of the Espionage Act making it a criminal offense to cause or attempt to cause insubordination in the military or to obstruct recruiting-the same sections under which Debs was charged. Hand had said:

If one stops short of urging upon others that it is their duty or their interest to resist the law, it seems to me one should not be held to have attempted to cause its violation. If that be not the test, I can see no escape from the conclusion that under this section every political agitation which can be shown to be apt to create a seditious temper is illegal. ${ }^{2}$

Before the decision in Debs, Hand had written to Holmes, urging his views about tolerance in terms remarkably suggestive of Holmes's later dissent in Abrams. ${ }^{3}$ In another letter, written shortly after Debs was decided, Hand criticized the opinion and applied his own objective test to the facts of that case: "his responsibility only began when the words were directly an incitement." ${ }_{4}$ Holmes answered, however, that he did not get Hand's point:

As to intent under the Espionage Act, I believe I have said nothing except to note that under the instructions the jury must be taken to have found that Debs's speech was intended to obstruct and

1244 F. 535 (1917).

$2 I d$. at 540 .

3 See Letter from Learned Hand to Oliver Wendell Holmes, June 22, 1918, reprinted in

1 HOLMES-LASKI LETTERS 114 n.2 (M. Howe ed. abr. 1963):

Opinions are at best provisional hypotheseses, incompletely tested. The more they are tested, after the tests are well scrutinized, the more assurance we may assume, but they are never absolutes. So we must be tolerant of opposite opinions or varying opinions by the very fact of our incredulity of our own.

Ragan, Justice Oliver Wendell Holmes, Jr., Zechariah Chafee, Jr., and the Clear and Present Danger Test for Free Speech: The First Year, 1919, 58 J. AM. HIst. 24 (1971).

4 Letter from Learned Fand to Oliver Wendell Holmes, c. Apr. 1, 1919, on file in the Holmes Papers, Box 48, Folder 30, Harvard Law Library, Ms. Treasure Room. 
tended to obstruct-and except further that evidence was held admissible as bearing on intent. Even if absence of intent might not be a defense I suppose that the presence of it might be material. ${ }^{5}$

Nor did he see how Hand's formulation differed from the clear and present danger test of Schenck. Referring to the Masses case, he continued:

I haven't time even now to recur to your decision but I take it that you agree that words may constitute an obstruction within the statute, even without proof that the obstruction was successful to the point of preventing recruiting. That I at least think plain.

Indeed, in Masses Hand had allowed that words may be an obstruction - "One may obstruct without preventing. ..."6_-but he expressly noted his view that expressions of opinion with the ability to obstruct were "limited to the direct advocacy of resistance."

A month after his disappointing exchange with Justice Holmes and shortly after the appearance of the New Republic article, Judge Hand wrote to Professor Freund: ${ }^{8}$

Your article in last week's "New Republic" was a great comfort to me. I had supposed that in holding such views about the Espionage Act I was in a minority of one in the profession, and that is rather too slim a party to carry a banner. You express my own opinion much better than I could myself and in your distinguished company I shall take heart of grace to believe I am right, even with the whole Supreme Court the other way. If you are interested in sports of judicial opinion you can find the judicial variant with which $I$ tried to stop the way in Masses Publishing Co. v. Patten, 244 Fed. R. 535.

I own I was chagrined that Justice Holmes did not line up on our side; indeed, I have so far been unable to make him see that he and we have any real differences and that puzzles me a little.

Just as Holmes had not yet seen that he and Hand had any real differences, so Hand did not seem to think that Freund's position differed from his own. Yet Freund, of course, would not have admitted

5 Letter from Oliver Wendell Holmes to Learned Hand, Apr. 3, 1919, on file in the Hand Papers, Box 103, Folder 23, Harvard Law Library, Ms. Treasure Room. This letter is quoted with the kind permission of Professor Grant Gilmore, Justice Holmes's literary executor, Mr. Norris Darrell, Judge Hand's literary executor, and Professor Gerald Gunther, who is writing a biography of Judge Hand.

$6244 \mathrm{~F}$. at 541.

$7 I d$.

8 Letter from Learned Hand to Ernst Freund, May 7, 1919, on file in the Hand Papers, Box 21, Folder 1, Harvard Law Library, Ms. Treasure Room. This letter is reproduced in its entirety with the kind permission of Mr. Darrell and Professor Gunther. 
of even a narrow exception for a doctrine of "indirect provocation, i.e., implied or inferential incitement." Although they were apparently united in opposition to Debs, it would be facile-and probably erroneous-to presume that Hand and Freund were agreed on a position alternative to that taken by Holmes.

In any case, Holmes was quite clear that Professor Freund was off the mark. In the last paragraph of his New Republic article, Freund made his only point with which Holmes at that time agreed-that a wise government would not have pressed the case against Debs. Holmes wrote to Pollock that "the inevitable result was that fools, knaves, and ignorant persons were bound to say he was convicted because he was a dangerous agitator and that obstructing the draft was a pretence." Holmes thought the entire Schenck-Frohwerk-Debs sequence the unfortunate consequence of a collision between a singleminded government and an opposition pitiable for its ignorance. $\mathrm{He}$ "greatly regretted"10 having to write the opinions, thinking forgiveness the better course, ${ }^{11}$ but he had no doubt of what the law demanded. ${ }^{12}$

In a letter to Harold Laski, who had called his attention to Freund's article, ${ }^{13}$ Holmes enclosed a letter that he had drafted to Herbert Croly, the editor of the New Republic, but had decided not to send. ${ }^{14}$ After noting that the constitutionality of the Espionage Act had been settled in Schenck, and that "it was impossible to have a rational doubt about the law," Holmes defended the tests of intent and natural tendency applied in Debs:

Freund's objection to a jury "guessing at motive, tendency and possible effect" is an objection to pretty much the whole body of the law, which for thirty years I have made my brethren smile by insisting to be everywhere a matter of degree. In Nash $v$. United States, 229 U.S. 373 the same objections were urged to criminal prosecutions under the Sherman Act in view of the interpretation of the Statute by the Standard Oil \& Tobacco Cases-but I answered p. 377 that "the law is full of instances where a man's fate depends on his estimating rightly, that is, as the jury subsequently estimates it, from matters of degree," and illustrated by

92 Holmes-Pollock LeTters 7 (M. Howe ed. 1941), see 1 Holmes-LASKI LeTters, supta note 3 , at 142 .

101 HoLmes-LASRI LeTTERs, supra note 3, at 142.

11 Id. at 147. Holmes believed from the outset that Debs should be pardoned. Id.; 2. Holme5-PoLcock LeTTERs, supra note 9, at 11.

121 Holmes-LASTI LETTERs, supra note 3, at 153; 2 Holmes-PoInock LETTERs, supra note 9 , at 11 . Indeed, Holmes suspected that Chief Justice White had assigned the opinion to him because he would go farthest in favoring freedom of speech. Id. at 7.

131 HoLMEs-LAsKT LETTERs, supra note 3, at 151.

14 Id. at $152-53$. 
murder and manslaughter-showing that a man might be hanged for consequences that he neither intended nor foresaw (apart from statute of course).

This is not the stuff of which "robust debate" is made. It envisions a first amendment different in kind, not in degree, from that which eventually evolved, from that which has a "penumbra" to give it "breathing space" and which provides protection against even a slight "chilling effect." As Professor Kalven has noted, Debs was for Holmes a routine criminal appeal.

Why was it Abrams and not Debs that finally stirred Justice Holmes to speak seriously about freedom of speech? Justice Frankfurter was at some pains to explain the course that led Holmes from Schenck to Abrams. Imagining Holmes with Schenck before him, Frankfurter observed, with some discomfort: "One whose whole outlook on life was profoundly influenced by his Civil War experience was bound to acquiesce in some subordination of private opinion during war which he would find unwarranted in times of peace."15 Justice Holmes did say things in Schenck ${ }^{16}$ and particularly in his Abrams dissent ${ }^{17}$ to indicate a concept of the first amendment that contracts in time of war. In the letter that he did not send to the editor of the New Republic, Holmes said, "I think the clauses under consideration [in Debs] not only were constitutional but were proper enough while the war was on. When people are putting out all their energies in battle I don't think it unreasonable to say we won't have obstacles intentionally put in the way of raising troops-by persuasion any more than by force."18

The war-peace distinction does not, however, explain the difference between Debs and Abrams to which Holmes responded. Debs was decided well after the Armistice of November, 1918; Abrams was decided some six months after Debs. But Debs gave his speech and Abrams published his leaflet while the war was raging. If Holmes somehow perceived a difference between the situations in which the two men acted, the clear and present danger test is too imprecise to explain what it might have been.

Justice Frankfurter hypothesized that the abuses of the wartime "period of hysteria undoubtedly focused the attention of Mr. Justice Holmes on the practical consequences of a relaxed attitude toward" the first amendment. ${ }^{19}$ Yet it seems unlikely that the abuses to which

16 F. Frankfurter, Mr. JUSTice Holmes and the Supreme Court 76-77 (2d ed. 1961). 16249 U.S. at 52.

17250 U.S. at 630.

18 I Holmes-LASKI LETTERs, supra note 3, at 153 (emphasis in original).

19 F. Frankfurter, supra note 15 , at 79. 
Frankfurter attributed Justice Holmes's heightened sensitivity were any more in evidence at the time of the Abrams dissent than they were six months earlier, when Holmes wrote the letter to Croly defending the decision in Debs.

It was, of course, precisely such abuses, stamped with the imprimatur of judicial process, to which Freund adverted in his short critique of Debs: "while the jury may have been a protection against governmental power when the government was a thing apart from the people, its checking function fails where government policies are supported by Majority opinion." It is both plausible and intriguing to think that the criticism of Debs in the Freund article and in Hand's correspondence with Justice Holmes throughout the period between Debs and Abrams compelled Holmes to recognize the dangers of Debs's casual approach and influenced his thinking about the value of political speech, even in time of war. ${ }^{20}$

Douglas H. Ginsburg

20 See New York Times Co. v. United States, 404 U.S. 713 (1971); Kalven, Foreword, Even When A Nation Is At War-, The Supreme Court, 1970 Term, 85 HARv. L. REv. 3 (1971). 